\title{
THE
}

\section{Inhibition of Bacterial Growth and Biofilm Production by Constituents from Hypericum spp.}

\author{
Simon A. Sarkisian \\ University of Rhode Island \\ J. Janssen \\ H. Matta \\ G. E. Henry \\ Kerry L. LaPlante \\ University of Rhode Island, kerrylaplante@uri.edu
}

See next page for additional authors

Follow this and additional works at: https://digitalcommons.uri.edu/php_facpubs

Terms of Use

All rights reserved under copyright.

\section{Citation/Publisher Attribution}

Sarkisian, S. A., Janssen, M. J., Matta, H. , Henry, G. E., LaPlante, K. L. and Rowley, D. C. (2012), Inhibition of Bacterial Growth and Biofilm Production by Constituents from Hypericum spp.. Phytother. Res., 26: 1012-1016. doi:10.1002/ptr.3675 Available at: https://doi.org/10.1002/ptr.3675

This Article is brought to you for free and open access by the Pharmacy Practice at DigitalCommons@URI. It has been accepted for inclusion in Pharmacy Practice Faculty Publications by an authorized administrator of DigitalCommons@URI. For more information, please contact digitalcommons-group@uri.edu. 
Authors

Simon A. Sarkisian, J. Janssen, H. Matta, G. E. Henry, Kerry L. LaPlante, and David C. Rowley

This article is available at DigitalCommons@URI: https://digitalcommons.uri.edu/php_facpubs/148 


\title{
Inhibition of Bacterial Growth and Biofilm Production by Constituents from Hypericum spp
}

\author{
S.A. Sarkisian ${ }^{a}$, M.J. Janssen ${ }^{b}$, H. Matta ${ }^{b}$, G.E. Henry ${ }^{b}$, K.L. LaPlante ${ }^{a, c}$, and D.C. Rowley ${ }^{a}{ }^{*}$ \\ ${ }^{a}$ College of Pharmacy, University of Rhode Island, Kingston, RI \\ bSusquehanna University, Selinsgrove, PA \\ 'VA Medical Center Infectious Diseases Research Laboratory, Providence, RI
}

\section{Abstract}

Biofilm embedded bacterial pathogens such as Staphylococcus spp., Escherichia coli, Pseudomonas aeruginosa, and Acinetobacter baumannii are difficult to eradicate and are major sources of bacterial infections. New drugs are needed to combat these pathogens. Hypericum is a plant genus that contains species known to have antimicrobial properties. However, the specific constituents responsible for the antimicrobial properties are not entirely known, nor have most compounds been tested as inhibitors of biofilm development. The investigation presented here tested seven secondary metabolites isolated from the species Hypericum densiflorum, Hypericumellipticum, Hypericum prolificum and Hypericum punctatum as inhibitors of bacterial growth and biofilm production. Assays were conducted against Staphylococcus epidermidis, Staphylococcusaureus, clinical methicillin-resistant Staphylococcus aureus (MRSA), Pseudomonas aeruginosa, Escherichia coli, and Acinetobacter baumannii. Five of the seven compounds demonstrated growth inhibition against the Gram-positive bacteria with minimum inhibitory concentrations (MIC) ranging from $1.95 \mu \mathrm{g} / \mathrm{mL}$ to $7.81 \mu \mathrm{g} / \mathrm{mL}$. Four of the secondary metabolites inhibited biofilm production by certain Gram-positive strains at sub-MIC concentrations.

\section{Keywords}

antibacterial agents; Hypericum; acylphloroglucinol; Staphylococcus; biofilm

\section{INTRODUCTION}

\begin{abstract}
Bacterial resistance to many of our current antibiotics is sharply increasing, thereby creating a critical need to develop novel antimicrobial drugs (Spellberg et al., 2004). Antimicrobials of plant origin have enormous therapeutic potential. Not only could they help mitigate infectious diseases, but they may also lack adverse side effects often associated with existing antimicrobial agents, including hypersensitivity, allergic reaction, and immunosuppression (Iwu et al., 1999; Mukherjee et al., 2002). Previous investigations have demonstrated the effectiveness of plant metabolites from traditional herbs against Gram-positive and Gramnegative microorganisms (Dall'agnol et al., 2005; Gibbons, 2004; Mukherjee et al., 2002). In particular, studies involving members of the genus Hypericum have suggested that their secondary metabolites possess promising antimicrobial properties.
\end{abstract}

*Corresponding Author: David C. Rowley, Ph.D., Department of Biomedical and Pharmaceutical Sciences, University of Rhode Island, 41 Lower College Road, Kingston, Rhode Island 02881, office: 401.874.9228; fax: 401.874.5787; drowley@uri.edu. 
The plants of the Clusiaceae (Guttiferae) family consist of more than 1000 species of which Hypericum is the most widely studied genus (Dall'agnol et al., 2005). These plants are commonly found as herbs, shrubs or small trees and are distributed chiefly in the temperate regions of the world. Hypericum has been used in folk medicine dating back more than 2400 years, thereby suggesting the therapeutic potential of many species. Records indicate that Cherokee, Iroquois, and Montagnais American Indian tribes used Hypericum perforatum, also known as St. John's wort, as a febrifuge/cough medicine (Saddiqe et al., 2010).

There is a growing interest in Hypericum secondary metabolites because of their wide range of biological activities. Phytochemical investigations on Hypericum perforatum, for instance, have led to the isolation of active antimicrobial compounds, which include naphthodianthrones and phloroglucinols (Saddiqe et al., 2010). Owing to these findings, we were inspired to expand the search for new antibacterial agents to include other Hypericum species. Here we report the biological evaluation of seven phloroglucinol derivatives from $H$. densiflorum, $H$. ellipticum, $H$. prolificum and $H$. punctatum for their antibacterial properties. The compounds were tested for inhibition of bacterial growth and biofilm formation against a panel of clinically relevant pathogens. The panel was comprised of Staphylococcus epidermidis, Staphylococcus aureus, clinical methicillin-resistant $S$. aureus (MRSA), Pseudomonasaeruginosa, Escherichia coli, and Acinetobacter baumannii. Five of the compounds demonstrated potent antimicrobial effects against the Gram-positive pathogens. Additionally, four of the secondary metabolites attenuated biofilm formation at concentrations below the minimum inhibitory concentration.

\section{MATERIALS AND METHODS}

\section{Chemicals and Instrumentation}

NMR spectra were recorded on a JEOL ECP $400 \mathrm{MHz}$ spectrometer $\left({ }^{1} \mathrm{H}, 400 \mathrm{MHz} ;{ }^{13} \mathrm{C}\right.$, $100 \mathrm{MHz}$ ) using $\mathrm{CDCl}_{3},\left(\mathrm{CD}_{3}\right)_{2} \mathrm{CO}$ and DMSO-d $\mathrm{d}_{6}$ as solvents and TMS as internal standard. Gradient HMQC and HMBC data were obtained using standard pulse programs. MS analyses were carried out on a Q-Star Elite (Applied Biosystems MDS) mass spectrometer equipped with a Turbo Ionspray source (University of Rhode Island). HRMS data were acquired using electrospray ionization on an Agilent G6520A Q-TOF high resolution mass spectrometer (CUNY, Hunter College). Preparative HPLC was performed using a Waters Delta 600 system equipped with a Waters 2487 dual wavelength absorbance detector. Column chromatography (CC) was performed using Fisher Scientific silica gel (230-400 mesh), and analytical TLC was performed using Sigma-Aldrich polyester backed plates precoated with silica gel $\mathrm{UV}_{254}$. All solvents were HPLC grade and were obtained from Fisher Scientific and Aldrich Chemical Co.

\section{Plant material}

All plant samples were collected and identified by Joseph A. Isaac of Civil and Environmental Consultants, Pittsburgh, Pennsylvania (PA), USA. The aerial portions (leaves and stems) were collected and voucher specimens have been deposited at the Carnegie Museum Herbarium in Pittsburgh, PA. H. densiflorum Pursh. was collected in Westmoreland County, PA, in June 2005 (voucher \#18640) and September 2007 (voucher \# 19442). Hypericum ellipticum (voucher \#20714) was collected in Clearfield County, PA, in August 2009. H. prolificum L. (voucher \#18641) was collected in Lawrence County, PA, in June 2005 and $H$. punctatum Lam., spotted St. John's wort, (voucher \#18944) was collected in Lawrence County, PA, in September 2005. 


\section{Extraction and isolation procedures}

The aerial parts of $H$. punctatum were dried and ground to a fine powder using a coffee grinder. The powdered plant material $(255 \mathrm{~g})$ was extracted with acetone $(3 \times 1.1 \mathrm{~L})$ followed by methanol $(3 \times 1.0 \mathrm{~L})$ at room temperature. The solvents were allowed to percolate for one night each time. The acetone and methanol extracts were concentrated in vacuo. The acetone extract ( $15.5 \mathrm{~g})$ was subjected to silica gel CC, eluting with an acetonehexanes stepwise solvent gradient (5:95 to 100:0, v/v) to afford nine fractions (A1-A9). Fraction A5 $(520 \mathrm{mg})$, eluted with acetone-hexanes $(1: 4, \mathrm{v} / \mathrm{v})$, was chromatographed further by silica gel CC using ethyl acetate-hexanes (1:9 to 1:4, v/v) to afford sub-fractions B1-B6. Subfraction B3 (294.2 mg) was purified by semi-preparative HPLC on an Atlantis dC18 column $(5 \mu \mathrm{m}, 19 \times 150 \mathrm{~mm}$, methanol:water $(85: 15$, v/v), isocratic elution, flow $10 \mathrm{~mL} /$ $\mathrm{min})$, to afford compound $\mathbf{1}(40.2 \mathrm{mg})$ and compound $\mathbf{2}(55.1 \mathrm{mg})$ as yellow solids. The NMR spectroscopic data of $\mathbf{1}$ and $\mathbf{2}$ are consistent with those reported in the literature (Rios and Delgado, 1992). Compounds 3-7 were previously isolated from three Hypericum species: H. densiflorum, H. ellipticum and H. prolificum. Compounds $3(54.7 \mathrm{mg})$ and 4 $(36.9 \mathrm{mg}$ ) were isolated from a hexanes extract of the aerial portions of $H$. densiflorum, whereas compound $\mathbf{5}(110.4 \mathrm{mg})$ was isolated from an acetone extract of the sample plant. The structures were confirmed on the basis of NMR spectroscopic data (Henry et al., 2009). Compound $\mathbf{4}$ had been previously reported from $H$. olympicum and prepared by synthesis (Gibbons et al., 2009), and compound 5 was recently isolated from $H$. elegans (Nedialkov et al., 2011). However, compound $\mathbf{3}$ is only known from H. densiflorum. Compound $\mathbf{6}$ (28.0 $\mathrm{mg}$ ) was isolated from an acetone extract of the aerial parts of $H$. ellipticum. The structure was elucidated on the basis of NMR spectroscopic data, as previously described (Manning et al., 2011). This natural product is currently known only in $H$. ellipticum. Compound 7 (1.0 $\mathrm{g}$ ) was isolated from the hexanes extract of $H$. prolificum as previously reported (Henry et al., 2006), and characterized on the basis of NMR spectroscopic data. This compound has so far only been reported in this species. NMR spectra of compounds 1-7 are provided as supplementary data.

\section{Microorganisms and culture conditions}

S. epidermidis (RP62A; ATCC 35984), S. aureus (ATCC 35556), clinical methicillinresistant $S$. aureus, $P$. aeruginosa (ATCC 27853), E. coli (ATCC 25922), and A. baumannii (ATCC 17978) were obtained from the Veterans Affairs Medical Center (VAMC) in Providence, Rhode Island and maintained in tryptic soy broth (Difco, Becton Dickinson) at $-80{ }^{\circ} \mathrm{C}$. All strains were incubated on tryptic soy agar (Difco, Becton Dickinson) at $37^{\circ} \mathrm{C}$ for $24 \mathrm{~h}$. The clinical MRSA isolate is a biofilm-producing strain that was obtained in 2004 from the blood of an infected patient at the VAMC in Providence, RI.

\section{Antimicrobial activity}

Bacterial cells $\left(10^{5} \mathrm{CFU} / \mathrm{mL}\right)$ were inoculated into Mueller-Hinton broth (Difco, Becton Dickinson) at $200 \mu \mathrm{L} /$ well in 96 -well microtiter plates. The minimum inhibitory concentration (MIC) of each pure compound was determined following methods recommended by the Clinical and Laboratory Standards Institute (CLSI, 2005). Briefly, twofold serial dilutions of each compound were added to wells containing bacterial cells. After $24 \mathrm{~h}$ of incubation at $37^{\circ} \mathrm{C}$, MICs were determined by visually inspecting each well for bacterial growth. The minimum bactericidal concentration (MBC), defined as the minimum concentration required to kill $99.9 \%$ of a bacteria inoculums, was determined by reinoculating $20 \mu \mathrm{L}$ of each culture medium from the microtiter plate wells onto tryptic soy agar plates. After $24 \mathrm{~h}$ of incubation at $37^{\circ} \mathrm{C}$, MBCs were determined by visually inspecting the agar plates for bacterial growth. All MIC and MBC measurements were performed at least in duplicate. 


\section{Biofilm Inhibition}

Hypericum constituents that demonstrated growth inhibitory properties against staphylococci were tested for their ability to prevent biofilm formation by planktonic $S$. aureus and $S$. epidermidis. Biofilm production was quantified using a microtiter plate assay (Stepanovic et al., 2000). After overnight growth on tryptic soy agar (Difco, Becton Dickinson), stationary cultures of the biofilm-producing reference strains $S$. aureus (ATCC 35556), S. epidermidis (RP62A; ATCC 35984), and non-biofilm producing staphylococci were evaluated. A stable biofilm-negative mutant, M7, from the wild-type $S$. epidermidis RP62A served as the non-biofilm control. After $24 \mathrm{~h}$ of incubation at $37^{\circ} \mathrm{C}$, tryptic soy broth (Bacto, Becton Dickinson) and planktonic bacteria were removed by gently washing with sterile normal saline. The minimum biofilm inhibitory concentration (MBIC), which is the lowest concentration of an antimicrobial agent that results in no detectable biofilm growth, was quantified by staining the bacteria with $2 \%$ crystal violet and measuring optical density at $570 \mathrm{~nm}$ (Synergy 2, Bio-Tek Instruments, Inc, Winooski, VT). Wells containing sterile medium served as blanks for all absorbance readings and the non-biofilm isolate was used as a negative control. All tests were conducted in quadruplicate and the results were averaged.

\section{RESULTS AND DISCUSSION}

Each of the seven secondary metabolites was first tested for growth inhibitory properties against the panel of pathogens. Compounds 1-5 demonstrated potent growth inhibition of the Gram-positive bacteria (Table 1), with MIC and MBC values ranging from $1.95 \mu \mathrm{g} / \mathrm{mL}$ to $7.81 \mu \mathrm{g} / \mathrm{mL}$. The MBC values closely mirrored the MIC values, suggesting a bactericidal mechanism of action. A comparison of MIC values for constituents 3-5 shows that the acyl group modulates potency only minimally. The benzoyl derivative $\mathbf{5}$, isolated from $H$. densiflorum, is the most potent congener in this series, registering a MIC of $1.95 \mu \mathrm{g} / \mathrm{mL}$ against biofilm-producing $S$. aureus.

Additional structure-activity relationships are apparent from the variable activities of the compounds. Attachment of the geranyl group to either $\mathrm{C} 3$ of the phloroglucinol ring ( $\mathbf{1}$ and 2) or the C2-oxygen (3-5) had little effect on the antibacterial properties of the Hypericum constituents. However, a previous study reported that similar acylphloroglucinol compounds from Hypericum beanii lacking the geranyl chain were 2-4 fold less active against $S$. aureus (Shiu and Gibbons, 2006), highlighting the importance of this structural feature. Compounds $\mathbf{6}$ and $\mathbf{7}$ did not produce any measurable activity against the Gram-positive bacteria. Introduction of a methyl group and a second prenyl group (compound 6), leading to loss of aromaticity in the phloroglucinol ring, resulted in loss of antibacterial activity. Elaboration of the terpene moiety to include an additional two isoprene units (compound 7) also abolished the antibacterial effects. The additional cyclization would limit conformational flexibility of the terpene unit. The additional prenyl groups also increase the lipophilicity, which would likely limit aqueous solubility and therefore decrease intracellular concentrations (Appendino et al., 2008). Winkelmann et al. reported modest antistaphylococcal activity ( $32 \mu \mathrm{g} / \mathrm{mL}$ ) for a related acylphloroglucinol lacking one of the additional isoprene units of $\mathbf{7}$, further demonstrating the detrimental effects of the cyclization and/or increased lipophilicity (Winkelmann et al., 2003).

Although five of the Hypericum compounds displayed growth inhibitory effects against the Staphylococcus test strains, all were inactive against the Gram-negative bacteria (E. coli, $P$. aeruginosa, A. baumanii) at the highest test concentration of $125 \mu \mathrm{g} / \mathrm{mL}$. Structural differences between Gram-positive and Gram-negative bacterial cell walls may account for the variable activities. Gram-negative bacteria possess an outer lipopolysaccharide membrane surrounding the cell wall whereas Gram-positive bacteria do not. The lack of an 
outer lipopolysaccharide membrane in the Gram-positive bacteria may allow increased permeability of Hypericum metabolites into cells (Tian et al., 2009). These results are in agreement with previous studies of Hypericum extracts that have shown weak to no activity against E. coli (Bussmann et al., 2010; Jayasuriya et al., 1989; Rabanal et al., 2002; Schwob et al., 2002; Vajs et al., 2003).

Due to growing interest in antimicrobial agents that can treat infections caused by biofilm forming bacteria, the active compounds (1-5) were tested for their ability to attenuate biofilm production by each of the Staphylococcus species. The MBIC values of the Hypericum metabolites ranged from $1.95 \mu \mathrm{g} / \mathrm{mL}$ to $7.81 \mu \mathrm{g} / \mathrm{mL}$. Compound 2 , isolated from $H$. punctatum, displayed the most potent biofilm inhibition against $S$. aureus and $S$. epidermidis at an MBIC of $1.95 \mu \mathrm{g} / \mathrm{mL}$. Compounds 1, 2, and $\mathbf{3}$ also inhibited biofilm formation at concentrations below their respective MIC and MBC values against some test strains. Compounds with 2-methylpropanoyl groups ( $\mathbf{1}$ and $\mathbf{3}$ ) consistently demonstrated MBIC values at or below their respective MIC values. Interestingly, a study by Socolsky et al. showed that other acylphloroglucinols isolated from Elaphoglossum yungense produced a modest increase in the amount of biofilm of $S$. aureus and $P$. aeruginosa at $10 \mu \mathrm{g} / \mathrm{mL}$, despite reducing growth. (Socolsky et al., 2010).

The results of these studies add to growing knowledge of the antimicrobial properties of acylphloroglucinol metabolites. Other studies have reported acylphloroglucinol derivatives possessing antimicrobial activity against staphylococci (Gibbons et al., 2005; Henry et al., 2009; Ishiguro et al., 1994; Pecchio et al., 2006; Schempp et al., 1999; Winkelmann et al., 2001; Winkelmann et al., 2003). A study by Socolsky et al. reported that acylphloroglucinols containing an additional chromene substituent demonstrate antimicrobial activity against $P$. aeruginosa, indicating that certain acylphloroglucinols may possess useful antimicrobial effects against Gram-negative pathogens (Socolsky et al., 2010). While a detailed mechanism of action for the antimicrobial activities of acylphloroglucinols remains to be determined, Hubner and colleagues showed that reduced sensitivity of $S$. aureus to hyperforin did not lead to a cross resistance against clinically used antibiotics (Hubner, 2003), therefore suggesting a possible unique mechanism of action. Shiu et al. found that certain acylphloroglucinols retained activities against tetracyline, fluoroquinolone, and macrolide drug-resistant strains, thereby also suggesting alternate mechanisms of action (Shiu and Gibbons, 2006). These studies further highlight the promise of investigating acylphloroglucinol derivatives as novel agents to treat bacterial disease.

Several of the metabolites in this study have previously demonstrated biological activities in other medically relevant assays. Compounds $3, \mathbf{4}, \mathbf{5}$ and $\mathbf{7}$ are reported to have antitumor activity with $\mathrm{IC}_{50}$ values ranging from 4.1 to $36 \mu \mathrm{M}$ (Henry et al., 2009; Henry et al., 2006). Additionally, compounds $\mathbf{3}, \mathbf{4}$, and $\mathbf{5}$ display antioxidant activity and cyclooxygenase (COX) inhibition (Henry et al., 2006).

The potent anti-staphylococcal activity of the Hypericum constituents suggests that these deserve further consideration as novel antibacterial agents. $S$. aureus is recognized as an important human pathogen able to adapt and evolve in terms of its resistance traits and virulence factors; it is among the most important causes of human infections in both the hospital and community settings (Tang and Stratton, 2010). These bioactive secondary metabolites further highlight the potential for finding structurally new antibacterial agents from plants, and add to our understanding of structure-activity relationships for phloroglucinols that limit growth and biofilm production by pathogenic bacteria. 


\section{Supplementary Material}

Refer to Web version on PubMed Central for supplementary material.

\section{Acknowledgments}

This publication was made possible by RI-INBRE Grant \# P20RR016457 from the National Center for Research Resources (NCRR), a component of the National Institutes of Health (NIH). The contents of this work are solely the responsibility of the authors and do not necessarily represent the official views of NCRR or NIH. We gratefully acknowledge Suzanne Woodmansee of the LaPlante Infectious Diseases laboratory for assay assistance and interpretation. The views expressed are those of the authors and do not necessarily reflect the position or policy of the United States Department of Veterans Affairs. We thank Dr. Cliff Jones at the CUNY Mass Spectrometry Facility at Hunter College for HRMS analyses.

\section{REFERENCES}

Appendino G, Gibbons S, Giana A, Pagani A, Grassi G, Stavri M, Smith E, Rahman MM. Antibacterial cannabinoids from Cannabis sativa: a structure-activity study. J Nat Prod. 2008; 71:1427-1430. [PubMed: 18681481]

Bussmann RW, Malca-Garcia G, Glenn A, Sharon D, Chait G, Diaz D, Pourmand K, Jonat B, Somogy S, Guardado G, Aguirre C, Chan R, Meyer K, Kuhlman A, Townesmith A, Effio-Carbajal J, FriasFernandez F, Benito M. Minimum inhibitory concentrations of medicinal plants used in Northern Peru as antibacterial remedies. J Ethnopharmacol. 2010; 132:101-108. [PubMed: 20678568]

Clinical and Laboratory Standard Institute (CLSI). Performance standards for antimicrobial susceptibility testing M100-S15. CLSI. , editor. Wayne; Pennsylvania: 2005.

Dall'agnol R, Ferraz A, Bernardi AP, Albring D, Nor C, Schapoval EES, von Poser GL. Bioassayguided isolation of antimicrobial benzopyrans and phloroglucinol derivatives from Hypericum species. Phytother Res. 2005; 19:291-293. [PubMed: 16041769]

Gibbons S. Anti-staphylococcal plant natural products. Nat Prod Rep. 2004; 21:263-277. [PubMed: 15042149]

Gibbons S, Moser E, Hausmann S, Stavri M, Smith E, Clennett C. An anti-staphylococcal acylphloroglucinol from Hypericum foliosum. Phytochemistry. 2005; 66:1472-1475. [PubMed: 15921710]

Gibbons, S.; Malkinson, JP.; Shiu, W. Preparation and isolation of terpene-substituted acylphloroglucinols as antibacterials. PCT Patent WO/2009/034346. 2009.

Henry GE, Campbell MS, Zelinsky AA, Liu Y, Bowen-Forbes CS, Li L, Nair MG, Rowley DC, Seeram NP. Bioactive acylphloroglucinols from Hypericum densiflorum. Phytother Res. 2009; 23:1759-1762. [PubMed: 19441072]

Henry GE, Raithore S, Zhang Y, Jayaprakasam B, Nair MG, Heber D, Seeram NP. Acylphloroglucinol derivatives from Hypericum prolificum. J Nat Prod. 2006; 69:1645-1648. [PubMed: 17125240]

Hubner AT. Treatment with Hypericum perforatum L. does not trigger decreased resistance in Staphylococcus aureus against antibiotics and hyperforin. Phytomedicine. 2003; 10:206-208. [PubMed: 12725578]

Ishiguro K, Nagata S, Fukumoto H, Yamaki M, Isoi K. Phloroglucinol derivatives from Hypericum japonicum. Phytochemistry. 1994; 35:469-471.

Iwu, MW.; Duncan, AR.; Okunji, CO., editors. New antimicrobials of plant origin. ASHS Press; Alexandria, VA: 1999.

Jayasuriya H, McChesney JD, Swanson SM, Pezzuto JM. Antimicrobial and cytotoxic activity of rottlerin-type compounds from Hypericum drummondii. J Nat Prod. 1989; 52:325-331. [PubMed: 2746258]

Manning K, Petrunak E, Lebo M, González-Sarrías A, Seeram NP, Henry GE. Acylphloroglucinol and xanthones from Hypericum ellipticum. Phytochemistry. 2011; 72:662-667. [PubMed: 21338993]

Mukherjee PK, Saritha GS, Suresh B. Antimicrobial potential of two different Hypericum species available in India. Phytother Res. 2002; 16:692-695. [PubMed: 12410558] 
Nedialkov PT, Zheleva-Dimitrova D, Momekov G, Karlov K, Girreser U, Kitanov GM. Elegaphenone and 7-epi-clusianone, the major cytotoxic constituents of Hypericum elegans. Nat Prod Res. 2011 In press.

Pecchio M, Solis PN, Lopez-Perez JL, Vasquez Y, Rodriguez N, Olmedo D, Correa M, San Feliciano A, Gupta MP. Cytotoxic and antimicrobial benzophenones from the leaves of Tovomita longifolia. J Nat Prod. 2006; 69:410-413. [PubMed: 16562847]

Rabanal RM, Arias A, Prado B, Hernandez-Perez M, Sanchez-Mateo CC. Antimicrobial studies on three species of Hypericum from the Canary Islands. J Ethnopharmacol. 2002; 81:287-292. [PubMed: 12065165]

Rios MY, Delgado G. Polyprenols and acylphloroglucinols from Esenbeckia nesiotica. Phytochemistry. 1992; 31:3491-3494.

Saddiqe Z, Naeem I, Maimoona A. A review of the antibacterial activity of Hypericum perforatum L. J Ethnopharmacol. 2010; 131:511-521. [PubMed: 20659547]

Schempp CM, Pelz K, Wittmer A, Schopf E, Simon JC. Antibacterial activity of hyperforin from St John's wort, against multiresistant Staphylococcus aureus and gram-positive bacteria. Lancet. 1999; 353:2129. [PubMed: 10382704]

Schwob I, Bessiere JM, Dherbomez M, Viano J. Composition and antimicrobial activity of the essential oil of Hypericum coris. Fitoterapia. 2002; 73:511-513. [PubMed: 12385876]

Shiu WKP, Gibbons S. Anti-staphylococcal acylphloroglucinols from Hypericum beanii. Phytochemistry. 2006; 67:2568-2572. [PubMed: 17092525]

Socolsky C, Arena ME, Asakawa Y, Bardon A. Antibacterial prenylated acylphloroglucinols from the fern Elaphoglossum yungense. J Nat Prod. 2010; 73:1751-1755. [PubMed: 21043474]

Spellberg B, Powers JH, Brass EP, Miller LG, Edwards JE Jr. Trends in antimicrobial drug development: implications for the future. Clin Infect Dis. 2004; 38:1279-1286. [PubMed: 15127341]

Stepanovic S, Vukovic D, Dakic I, Savic B, Svabic-Vlahovic M. A modified microtiter-plate test for quantification of staphylococcal biofilm formation. J Microbiol Methods. 2000; 40:175-179. [PubMed: 10699673]

Tang Y-W, Stratton CW. Staphylococcus aureus: An old pathogen with new weapons. Clin Lab Med. 2010; 30:179-208. [PubMed: 20513547]

Tian F, Li B, Ji B, Yang J, Zhang G, Chen Y, Luo Y. Antioxidant and antimicrobial activities of consecutive extracts from Galla chinensis: The polarity affects the bioactivities. Food Chemistry. 2009; 113:173-179.

Vajs V, Vugdelija S, Trifunovic S, Karadzic I, Juranic N, Macura S, Milosavljevic S. Further degradation product of hyperforin from Hypericum perforatum (St John's Wort). Fitoterapia. 2003; 74:439-444. [PubMed: 12837358]

Winkelmann K, Heilmann J, Zerbe O, Rali T, Sticher O. New prenylated bi- and tricyclic phloroglucinol derivatives from Hypericum papuanum. J Nat Prod. 2001; 64:701-706. [PubMed: 11421727]

Winkelmann K, San M, Kypriotakis Z, Skaltsa H, Bosilij B, Heilmann J. Antibacterial and cytotoxic activity of prenylated bicyclic acylphloroglucinol derivatives from Hypericum amblycalyx. Z Naturforsch C. 2003; 58:527-532. [PubMed: 12939039] 

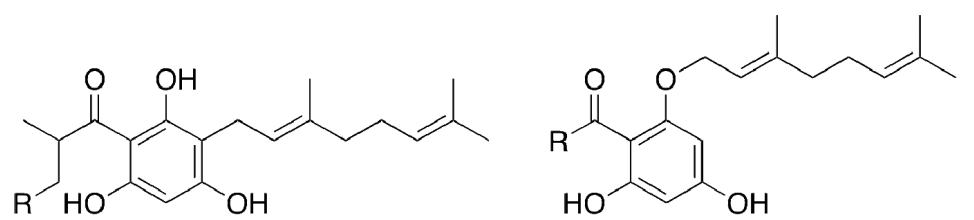

$\begin{array}{ll}1 & \mathrm{R}=\mathrm{H} \\ 2 & \mathrm{R}=\mathrm{CH} 3\end{array}$

$3 \mathrm{R}=\mathrm{i}-\mathrm{Pr}$

$4 \mathrm{R}=$ sec-Bu

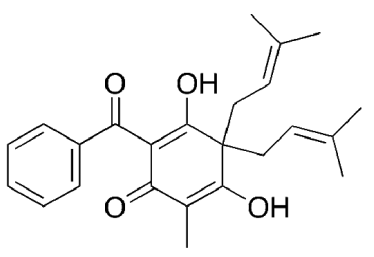

6

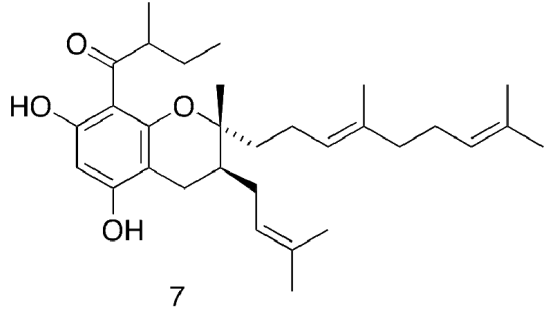

Figure 1.

Structures of Hypericum secondary metabolites. 


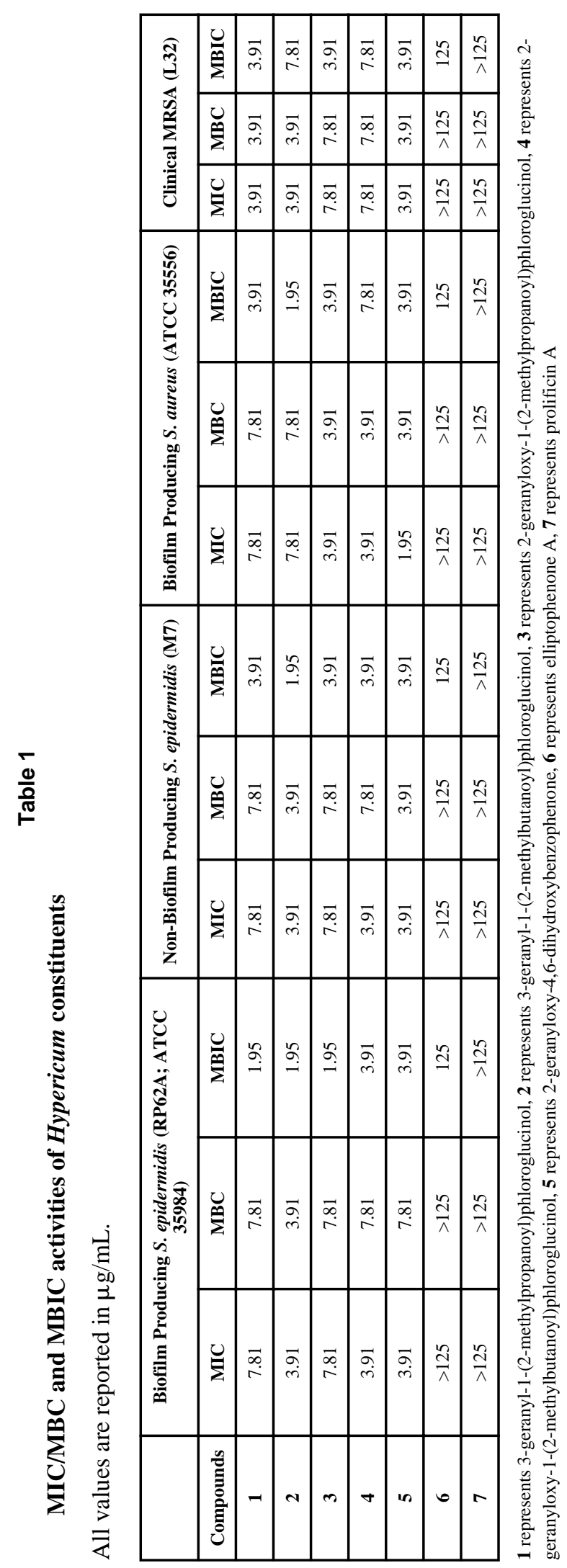

Phytother Res. Author manuscript; available in PMC 2013 July 01. 